\title{
PENGARUH PENGETAHUAN PARENTING TERHADAP KETERLIBATAN ORANGTUA DI LEMBAGA PAUD
}

\author{
Nhimas Galuh Adriana ${ }^{1}$, Zirmansyah $^{1}$ \\ ${ }^{1}$ Pendidikan Anak Usia Dini, Fakultas Psikologi dan Pendidikan, Universitas Al-Azhar \\ Indonesia, Komplek Masjid Agung Al-Azhar Jl. Sisingamangaraja, Jakarta Selatan, 12110 \\ E-mail: zirmansyah@uai.ac.id
}

\begin{abstract}
ABSTRAK- Keterlibatan orangtua merupakan salah satu bentuk partisipasi orangtua dalam pendidikan dan kehidupan anak. Keterlibatan orangtua penting untuk membantu tumbuh kembang anak, karena orang tua adalah pendidik utama bagi anak. Faktor yang dapat mempengaruhi keterlibatan orangtua diantaranya adalah pengetahuan parenting. Pengetahuan parenting adalah kemampuan mengenai cara menumbuhkembangkan dan mendidik anak melalui interaksi antara anak dan orangtua. Tujuan dari penelitian adalah untuk mendapatkan data tentang pengaruh Pengetahuan Parenting terhadap Keterlibatan Orangtua di lembaga PAUD. Metode yang digunakan adalah kuantitaif dengan teknik analisis regresi sederhana. Penelitian ini menggunakan SPSS 21 untuk menganalisis data yang telah diperoleh, dengan teknik pengumpulan data angket dan dokumentasi. Sampel pada penelitian ini adalah 30 orangtua dari peserta didik PAUD Hubbul Wathon dan PAUD Nusa Indah Bendungan Hilir Jakarta Pusat. Hasil penelitian menunjukkan terdapat pengaruh antara Pengetahuan Parenting terhadap Keterlibatan Orangtua. Hal ini ditunjukkan dari hasil rxy=0,371. Nilai R square, yang dapat disebut koefisien determinasi, yaitu 0,138 sehingga besaran pengaruh yang dihasilkan sebesar 13,8\% sedangkan sisanya yaitu 86,2\% dipengaruhi oleh faktor lainnya yang tidak diteliti dalam penelitian ini. Adapun saran yang dapat diberikan adalah hendaknya setiap orangtua dapat meningkatkan pengetahuannya mengenai parenting agar proses interaksi antara orangtua dan anak dalam menumbuhkembangkan dan mendidik dapat diberikan secara optimal. Dengan pengetahuan parenting yang dimiliki pula, orangtua dapat meningkatkan keterlibatannya dengan pihak lembaga PAUD untuk mendukung tumbuh kembang anak.
\end{abstract}

Kata Kunci: Pengetahuan Parenting, Keterlibatan Orang Tua , Lembaga PAUD.

ABSTRACT-Parental involvement is one form of parental participation in children's education and life. The involvement of parents is important to help child development, because parents are the primary educator for children. Factors that can influence parental involvement include parenting knowledge. Parenting knowledge is the ability to develop and educate children through interactions between children and parents. The purpose of the study was to obtain data on the influence of Parenting Knowledge on Parental Engagement in ECD institutions. The method used is quantitative with simple regression analysis techniques. This study uses SPSS 21 to analyze the data that has been obtained, with questionnaire data collection techniques and documentation. The sample in this study were 30 parents from PAUD Hubbul Wathon and Nusa Indah Bendungan Hilir PAUD students in Central Jakarta. The results showed that there was an influence between Parenting Knowledge on Parent Engagement. This is indicated by the results of rxy $=0.371$. The $R$ square value, which can be called the coefficient of determination, is 0.138 so the magnitude of the effect is $13.8 \%$ while the remaining $86.2 \%$ is influenced by other factors not examined in this study. The advice that can be given is that every parent should be able to increase their knowledge about parenting so that the process of interaction between parents and children in developing and educating can be given optimally. With the knowledge of parenting owned, parents can increase their involvement with PAUD institutions to support children's growth and development.

Keywords: Parenting Knowledge, Parent Engagement, PAUD Institution. 


\section{PENDAHULUAN}

\section{A. Latar Belakang}

$\mathrm{S}$ alah satu aspek terpenting dalam membantu kualitas tumbuh kembang anak adalah melalui peningkatan mutu pendidikan lembaga Anak Usia Dini, yang dilakukan dengan membangun kemitraan antara lembaga Pendidikan Anak Usia Dini dengan orangtua. Hal tersebut perlu dilakukan sebab orangtua merupakan pendidik pertama dan utama bagi anak dan paling mengerti akan anaknya, sedangkan lembaga PAUD berperan membantu orangtua dalam menjadikan pelaksanaan pendidikan lebih efektif dan optimal. Adanya kemitraan di antara keduanya dapat memberikan manfaat dimana antara lembaga PAUD dan orangtua akan saling melengkapi dan bersinergi dalam mendidik anak, dan keduanya dapat saling bertukar informasi mengenai pendidikan dan perkembangan anak.

Oleh sebab itu agar manfaat dari kemitraan dapat terwujud, maka pihak lembaga PAUD perlu membangun kemitraan dan mengajak agar orangtua berpartisipasi aktif terlibat dalam pendidikan dan perkembangan anak. Keterlibatan ini pada umumnya disebut dengan keterlibatan orangtua sebagaimana yang dinyatakan Bronfenbrenner (dalam Nurhadi, 2012: 117) bahwa Keluarga dan sekolah merupakan unsur yang dapat menentukan terjalinnya keterlibatan orangtua dimana sebuah survei yang dilakukan oleh para guru menunjukkan bahwa keterlibatan orangtua merupakan prioritas utama dalam peningkatkan kuliatas pendidikan. Keterlibatan orangtua pada dasarnya diperlukan pada setiap waktu terutama bagi anak di periode usia dini, dimana pada periode ini anak baru memulai mengembangkan pengetahuan, sikap, moral, emosionalnya serta pembentukan karakter.

Terkadang orangtua memandang bahwa dalam proses pendidikan seperti menentukan materi dan media pembelajaran serta memahami perkembangan anak pihak gurulah yang lebih paham, sehingga orangtua enggan untuk terlibat di dalamnya. Selain itu orangtua menganggap bahwa dalam pemberian pendidikan dan mengoptimalkan perkembangan anak hanyalah tanggung jawab pihak sekolah. Pada dasarnya sekolah tidak dapat berdiri sendiri dan membutuhkan partisipasi orangtua seperti dalam hal penyusunan dan pemilihan materi pembelajaran serta meneruskan pendidikan yang telah didapatkan oleh anak disekolah agar dapat diperkuat kembali dirumah, oleh sebab itu keterlibatan orangtua dalam pendidikan anak adalah hal yang penting dan bukan hal yang tidak perlu dilakukan karena peran aktif orangtua terhadap tumbuh kembang anaknya dapat memberikan kontribusi yang positif terhadap masa depan anak.

Sehingga sesibuk apapun orangtua sebaiknya orangtua tetap meluangkan waktu mereka dengan ikut berpartisipasi aktif dalam berbagai kegiatan yang dilaksanakan oleh lembaga PAUD untuk kesuksesan perkembangan anak dimasa depan.

Berdasarkan hasil observasi dan wawancara awal yang dilakukan peneliti di Lingkungan Pemukiman Bendungan Hilir, Jakarta pusat, khususnya RW 7 dan RW 8, fenomena yang tampak adalah masih banyak orangtua yang belum menyadari pentingnya partisipasi aktif dan keterlibatan orangtua dengan lembaga PAUD. Masih banyak orangtua yang tidak menghadiri dan terlibat dalam kegiatankegiatan anak di sekolah seperti rapat guru dan orangtua, pembagian rapot, tidak mengomunikasikan kepada pihak guru atau lembaga PAUD ketika anak tidak hadir di dalam kelas, serta orangtua masih menyerahkan kepada pihak lembaga PAUD terkait dengan pendaftaran sekolah di jenjang pendidikan selanjutnya dengan alasan tidak paham atau sedang berada di luar kota.

Faktor-faktor yang menyebabkan kurangnya keterlibatan orangtua di lembaga PAUD Lingkungan Bendungan Hilir, Jakarta Pusat disebabkan tingkat pendidikan orangtua yang rendah, bekerja dan menitipkan sang anak kepada orang lain sehingga menyebabkan kurangnya perhatian orangtua kepada anak. Faktor lain yang mungkin mempengaruhi keterlibatan orangtua dengan lembaga PAUD adalah pengetahuan orangtua mengenai parenting, dimana parenting merujuk kepada serangkaian aksi dan interaksi yang dilakukan orangtua untuk mendukung perkembangan anaknya. Interaksi ini menurut Berns dalam Raihanatul Jannah (2012: 22, vol. 4) berlangsung secara terus menerus yang dapat mempengaruhi anak juga orangtua.

Orangtua berperan dalam menentukan bagaimana anak akan tumbuh dan berkembang. 
Karena lingkungan utama bagi perkembangan anak adalah keluarga, maka keluarga berpengaruh kepada anak menjadi seperti apa kedepannya. Oleh sebab itu tugas orangtua adalah mencari tahu informasi mengenai parenting berkaitan dengan bagaimana cara menumbuhkembangkan (pemeliharaan fisik, pemberian kasih sayang dan kehangatan, menghargai anak, serta memberikan rangsangan yang dibutuhkan anak) dan mendidik (pengembangan nilai-nilai karakter) anak dengan baik dan benar. Pengetahuan parenting dapat diperoleh orangtua dengan berbagai cara seperti mengikuti penyuluhan yang diberikan lembaga PAUD, membaca buku mengenai parenting, membaca artikel-artikel. Pengetahuan parenting dapat membantu orangtua dalam mengoptimalkan upaya untuk membangun karakter anak, untuk menerapkan pola pengasuhan yang sesuai dengan nilai dan norma serta dapat menjadi jawaban dalam permasalahan yang dialami oleh orangtua. Parenting yang dilakukan secara optimal dan konsisten yang diberikan orangtua akan menjadi pengalaman dan akan berpengaruh terhadap fase kehidupan anak selanjutnya. Parenting akan lebih optimal apabila dilakukan dengan bekerjasama dengan pihak-pihak tertentu yang berkaitan dengan tumbuh kembang anak seperti lembaga PAUD dimana anak mengemban pendidikannya.

Orangtua dan guru dapat menjadi mitra dalam mewujudkan pertumbuhan dan perkembangan anak yang optimal sesuai dengan tahapan perkembangan anak, sehingga dapat meningkatkan pengetahuan dan keterampilan orangtua dalam mengasuh anak usia dini. Begitu juga dengan pihak guru di sekolah sebagai pendidik dan pengajar. Berdasarkan permasalahan di atas maka penulis tertarik untuk mengangkatnya sebagai topik dalam penelitian ini dengan judul "Pengaruh Pengetahuan Parenting Terhadap Keterlibatan Orangtua di Lembaga PAUD”.

\section{B. Identifikasi Masalah}

Dari latar belakang masalah yang telah diuraikan, dapat dilakukan identifikasi masalah sebagai berikut:

1. Kurangnya kesadaran akan pentingnya keterlibatan orangtua di lembaga PAUD.

2. Kurangnya partisipasi orangtua terkait dengan keterlibatan orangtua di lembaga PAUD.
3. Kurangnya kerjasama orangtua dengan lembaga PAUD.

4. Pengetahuan orangtua tentang parenting.

5. Proses parenting yang dilaksanakan oleh orangtua.

6. Keterbatasan bentuk keterlibatan orangtua yang diselenggarakan oleh lembaga PAUD.

7. Kurangnya peranan pihak lembaga PAUD untuk mengajak orangtua berpastisipasi aktif dalam keterlibatan orangtua.

8. Faktor pekerjaan,latar belakang pendidikan mempengaruhi keterlibatan orangtua di lembaga PAUD.

9. Pengaruh pengetahuan parenting terhadap bentuk keterlibatan orang tua di lembaga PAUD.

\section{Pembatasan Masalah}

Berdasarkan identifikasi masalah yang ada, maka masalah akan dibatasi pada Pengetahuan Parenting dan Keterlibatan Orangtua di lembaga PAUD.

\section{Perumusan Masalah}

Adapun rumusan masalah dalam penelitian ini adalah: "Apakah terdapat pengaruh Pengetahuan Parenting terhadap Keterlibatan Orangtua di lembaga PAUD?"

\section{KAJIAN TEORI}

\section{A. Pengertian Pengetahuan Parenting}

Siombo (2010: 10-11) menyatakan pengetahuan merupakan kemampuan untuk mengingat beberapa informasi dengan menggunakan pemikiran manusia yang memberikan arti serta tujuan, kemampuan untuk mengetahui tempat, kemampuan untuk mengetahui waktu, serta kemampuan untuk mengungkapkan pendapat dan lain sebagainya. Pengetahuan bersifat mengembangkan, menambah kesempurnaan karena dengan pengetahuan, subjek yang tadinya tidak tahu menjadi tahu, objek yang tadinya tidak diketahui menjadi diketahui, tetapi karena pengetahuan manusia bersifat terbatas dan tidak sempurna sehingga pengetahuan selalu tumbuh dan berkembang.

Menurut Hastuti (2015: 55), parenting adalah proses menumbuhkembangkan dan mendidik anak sejak pasca kelahiran hingga anak memasuki usia dewasa. Tugas ini umumnya ibu dan ayah yang melakukannya (orangtua biologis dari anak). Namun, bila 
orangtua bilogisnya tidak mampu melakukan pengasuhan maka kerabat dekat termasuk kakak, nenek, dan kakek, orangtua angkat, atau oleh institusi seperti panti asuhan yang umumnya mengambil tugas ini. Sementara menurut Kagan dalam Hidayati (2010: 11), parenting sebagai serangkaian keputusan tentang sosialisasi anak, dimana orangtua atau pengasuh harus melakukan berbagai hal agar anak mampu bertanggung jawab dan memberikan kontribusi sebagai anggota masyarakat, termasuk juga ketika anak menangis, marah, berbohong, dan tidak melakukan kewajibannya dengan baik.

\section{B. Pengertian Keterlibatan Orangtua di lembaga PAUD}

Menurut Undang-Undang No. 20 Tahun 2003 tentang Sistem Pendidikan Nasional pasal 28 dinyatakan bahwa maksud pendidikan usia dini adalah suatu upaya pembinaan yang diajukan kepada anak sejak lahir sampai dengan usia enam tahun yang dilakukan melalui pemberian rangsangan pendidikan untuk membantu pertumbuhan dan perkembangan jasmani dan rohani agar anak memiliki kesiapan dalam memasuki pendidikan lebih lanjut. Keberhasilan anak usia dini merupakan landasan bagi keberhasilan pendidikan pada jenjang berikutnya. Usia dini merupakan "usia emas" bagi seseorang, artinya bila seseorang pendidikan yang tepat pada masa itu maka diperoleh kesiapan belajar yang baik yang merupakan salah satu kunci utama bagi keberhasilan belajarnya pada jenjang berikutnya.

Di dalam pendidikan anak usia dini terdapat prinsip-prinsip yang dapat dijadikan sebagai acuan dalam pelaksanaan pembelajaran, yaitu: (1) belajar melalui bermain, (2) berorientasi pada perkembangan anak, (3) berorientasi pada kebutuhan anak, (4) berpusat pada anak, (5) pembelajaran aktif, (6) berorientasi pada pengembangan nilai-nilai karakter, (7) berorientasi pada pengembangan kecakapan hidup, (8) didukung oleh lingkungan yang kondusif, (9) derorientasi pada pembelajaran yang demokratis dan (10) pemanfaatan dan penggunaan media belajar, sumber belajar.

Menurut Wong dalam Lestari (2012: 60$61)$, keterlibatan orangtua adalah orangtua menunjukkan suatu derajat dalam hal keterikatan, berpengetahuan dan kesediaan untuk berperan aktif dalam aktivitas anak sehari-hari. Menurut Jeynes (dalam Amini 2015: 9, vol. 10), keterlibatan orangtua ialah partisipasi orangtua dalam proses pendidikan dan pengalaman bagi anak mereka, meliputi keterlibatan orangtua berbasis di rumah juga termasuk keterlibatan orangtua di sekolah.

Di dalam keterlibatan orangtua, terdapat berbagai bentuk keterlibatan yang dapat dilakukan oleh para orangtua. Menurut Kemendikbud (2016: 9-10) bentuk kemitraan sekolah, keluarga dan masyarakat dapat dilakukan sebagai berikut :

1. Penguatan Komunikasi Dua Arah

2. Pendidikan Orangtua (Parenting Education)

3. Kegiatan Sukarela

4. Belajar di Rumah

5. Kolaborasi dengan Masyarakat

Hornby (dalam Diandha, 2015: 64, vol. 2) menuliskan bahwa keterlibatan orangtua akan memberikan manfaat seperti meningkatkan kehadiran anak di sekolah, sikap dan perilaku, dan meningkatkan prestasi dan kepribadian mereka. Orangtua juga akan mendapat keuntungan tersendiri dari keterlibatan orangtua diantaranya kepercayaan diri dan kepuasan dalam mengasuh anak. Pihak lain yang yang juga akan merasakan manfaat dari keterlibatan orangtua yaitu guru atau sekolah tempat anak belajar, manfaat yang dapat diperoleh tersebut adalah akan terwujudnya suasana sekolah yang lebih baik, perbaikan pada perilaku dan sikap guru serta memperbaiki hubungan antara orangtua dan guru.

Faktor yang mempengaruhi tinggi rendahnya keterlibatan orangtua ditentukan oleh:

1. faktor orangtua, seperti keyakinan orangtua tentang pentingnya keterlibatan mereka dalam pendidikan, persepsi orangtua terhadap undangan keterlibatan dan konteks hidup orangtua.

2. Faktor anak, seperti Kondisi anak seperti usia anak, kemampuan belajar anak, perilaku anak, dan kelebihan dan keterbatasan anak.

3. Faktor guru dan orangtua, seperti sikap masing-masing guru dan orangtua yang kurang baik, perbedaan tujuan antara orangtua dan guru terhadap keterlibatan orangtua, dan perbedaan bahasa.

4. Faktor sosial, seperti faktor sejarah, faktor demografis orangtua, faktor politik, dan faktor ekonomi. 


\section{Kerangka berpikir}

Keterlibatan orangtua merupakan suatu hal yang penting untuk membantu tumbuh kembang anak, karena orangtua merupakan pendidik utama dan pertama bagi anak-anak mereka. Dengan orangtua terlibat aktif di dalamnya maka hal ini menunjukan keperdulian orangtua terhadap perkembangan dan pertumbuhan anak. Hal ini berkaitan dengan pengetahuan parenting yang dimiliki orangtua dimana seharusnya orangtua mengetahui bahwa orangtua berperan dalam membantu mengoptimalkan tumbuh kembang anak dengan terlibatan yang diselenggarakan oleh lembaga PAUD.

Sedangkan pengetahuan parenting adalah kemampuan yang dimiliki oleh orangtua yang berasal dari pengalaman yang diperoleh melalui proses refleksi dan juga upaya sadar untuk memenuhi kebutuhan berkaitan dengan suatu informasi mengenai menumbuhkembangkan dan mendidik anak secara optimal melalui proses interaksi antara anak dan orangtua hingga sang anak sudah memenuhi kriteria untuk disebut sebagai pribadi yang dewasa. Orangtua yang paham mengenai pengetahuan parenting yang baik dan benar akan berupaya untuk memenuhi kebutuhan anak sesuai dengan perkembangannya, salah satunya dengan mengetahui prinsip-prinsip pendidikan anak usia dini.

\section{Hipotesis Penelitian}

Berdasarkan kajian teori, hasil-hasil penelitian yang relevan dan kerangka berpikir maka dirumuskan hipotesis penelitian sebagai berikut: "terdapat pengaruh pengetahuan parenting terhadap keterlibatan orangtua di lembaga PAUD atau dengan kata lain $\mathrm{Ha}$ diterima dan Ho ditolak".

\section{METODE PENELITIAN}

\section{A. Tujuan Penelitian}

Tujuan dari penelitian ini adalah mengetahui pengaruh Pengetahuan Parenting terhadap Keterlibatan Orangtua di lembaga PAUD dalam menjawab permasalahan penelitian, dimana orangtua memiliki peranan penting dalam proses pengasuhan dan membantu tumbuh kembang anak secara optimal baik di rumah maupun terlibat dalam berbagai kegiatan anak di sekolah.

\section{B. Tempat dan Waktu Penelitian}

Penelitian dilakukan di lingkungan sekitar lembaga PAUD Hubbul Wathon RW 08 dan lembaga PAUD Nusa Indah RW 07 Bendungan Hilir Jakarta Pusat.

Pelaksanaan penelitian direncanakan pada bulan Mei 2017. Observasi dan wawancara awal telah dilakukan pada bulan September 2016 lalu selama kurang lebih dua minggu pada saat pelaksanaan Program Praktek Kerja Lapang (PKL).

\section{Metode Penelitian}

Penelitian dilakukan dengan menggunakan pendekatan kuantitatif. Menurut Sugiyono (dalam Alfianika, 2016: 8), metode penelitian kuantitaif merupakan metode penelitian yang menggunakan landaskan filsafat positivisme untuk meneliti populasi dan sampel, pengumpulan data, instrumen penelitian yang digunakan, analisis data yang bersifat kuantitatif, dengan tujuan untuk menguji hipotesis yang telah diterapkan.

\section{Populasi dan Sampel Penelitian}

1. Populasi Penelitian

Populasi pada penelitian ini kurang lebih sebanyak 69 orangtua murid yang menyekolahkan anak mereka di lembaga PAUD Hubbul Wathon dan PAUD Nusa Indah.

\section{Sampel Penelitian}

Sampel pada penelitian ini adalah orangtua yang menyekolahkan anak mereka di PAUD Hubbul Wathon dan PAUD Nusa Indah yang berusia 3-6 tahun yang berjumlah sebanyak 30 orangtua yang bersedia menjadi responden.

\section{E. Instrumen Penelitian}

1. Skala Pengetahuan Parenting

a. Definisi Konseptual

Pengetahuan Parenting adalah suatu bentuk kebenaran berkaitan dengan kemampuan seseorang dalam mengetahui suatu informasi yang diperoleh melalui pengalaman atau asosiasi, dimana informasi tersebut berkaitan dengan proses menumbuhkembangkan dan mendidik anak seperti memahami kondisi rumah yang mendukung pembelajaran, serta memahami tentang perkembangan anak 
sehingga orangtua dapat menerapkan keterampilan pengasuhan yang sesuai yang dilakukan sejak pasca kelahiran hingga anak memasuki usia dewasa.

\section{b. Definisi Operasional}

Pengetahuan Parenting adalah skor yang diperoleh dari orangtua dengan menggunakan skala Likert dengan mengacu kepada prinsip Pendidikan Anak Usia Dini, yaitu; (1) belajar melalui bermain, (2) Di dukung lingkungan yang kondusif, (3) berorientasi pada perkembangan anak,(4) berorientasi pada kebutuhan anak,(5) berpusat pada anak, dan (6) berorientasi pada pengembangan nilainilai karakter, (7) pemanfaatan sumber,media dan narasumber belajar.

2. Skala Keterlibatan Orangtua di lembaga PAUD

a. Definisi Konseptual

Keterlibatan Orangtua di lembaga PAUD adalah suatu derajat kesediaan orangtua untuk berperan aktif dalam proses pendidikan, pengalaman dan aktivitas anak usia dini baik pada saat di rumah maupun di sekolah. Hal ini dapat dilakukan melalui penyediaan berbagai pengalaman dan rangsangan yang dikembangkan secara terpadu dan menyeluruh sehingga baik orangtua, anak dan program yang dijalankan dapat memperoleh keuntungan. Pada Akhirnya anak dapat tumbuh dan berkembangsecara sehat dan optimal sesuai dengan nilai dan norma kehidupan serta anak memiliki kesiapan dalam memasuki pendidikan lebih lanjut.

b. Definisi Operasional

Definisi operasional Keterlibatan Orangtua di lembaga PAUD adalah skor yang diperoleh dari orangtua dengan menggunakan skala Likert, yang menggambarkan keterlibatan orangtua di lembaga PAUD mengenai (1) penguatan komunikasi dua arah, (2) pendidikan orangtua, (3) kegiatan sukarela, dan (4) belajar di rumah.

\section{F. Teknik Analisa Data}

Data hasil penelitian di analisis dengan menggunakan statistik deskriptif dan inferensial. Statistik deskriptif yang digunakan antara lain :mean, median, modus, standart devitiation, varian, range, maximum, minimum dan sum. Inferensial yang digunakan adalah regresi sederhana. Sebelum data dianalisis dengan statistik regresi, terlebih dahulu dipenuhi persyaratan analisisnya yakni data harus berdistribusi normal.

\section{HASIL DAN PEMBAHASAN}

\section{A. Hasil Penelitian}

1. Deskripsi Umum

a. Tempat Penelitian

Pendidikan Anak Usia Dini Hubbul Wathon adalah lembaga pendidikan anak usia dini yang terletak di Kelurahan Bendungan Hilir, Kecamatan Tanah Abang Jakarta Pusat yang berdiri sejak tahun 2004 dengan memiliki 3 orang guru dan satu orang Kepala PAUD. Pendidikan Anak Usia Dini Nusa Indah adalah lembaga pendidikan anak usia dini yang terletak terletak pada Kelurahan Bendungan Hilir, Kecamatan Tanah Abang Jakarta Pusat yang berdiri sejak tahun 2007 dengan memiliki 4 orang guru, 1 orang Kepala Sekolah, 1 orang sekretaris dan 1 orang bendahara.

b. Profil Subjek Penelitian

1) Profil Responden Penelitian a) Jenis Kelamin

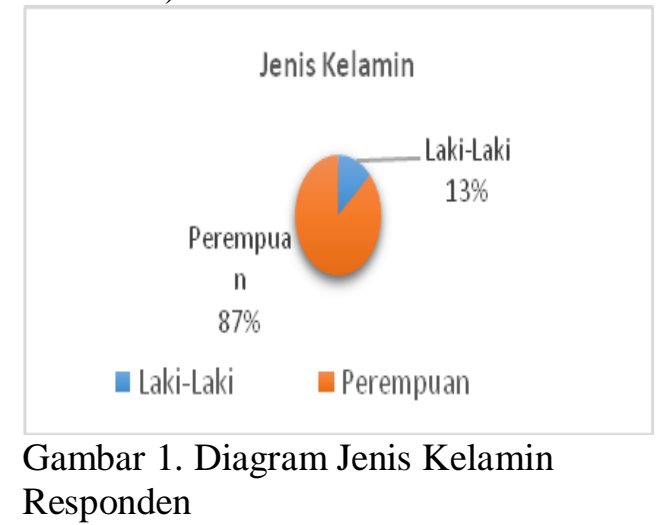

Responden 
b) Usia Responden

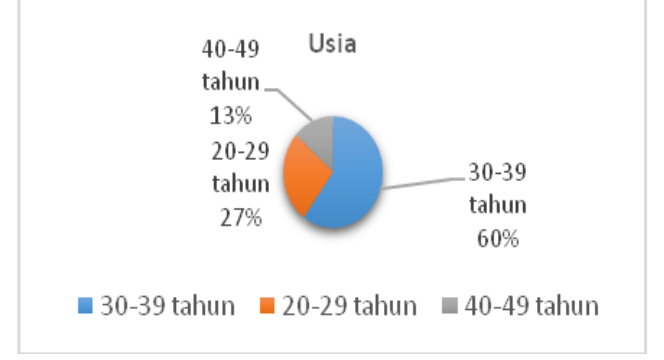

Gambar 2. Diagram Usia Responden

c) Pendidikan Responden

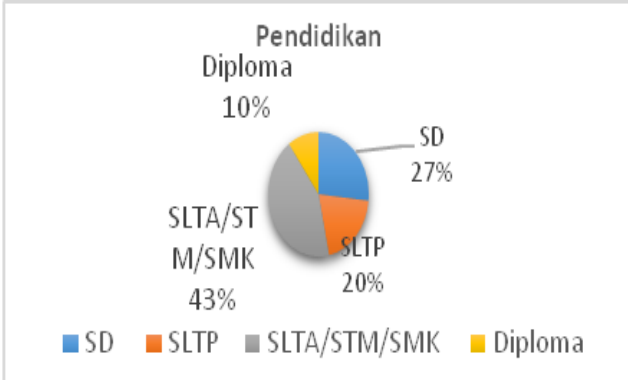

Gambar 3. Diagram Pendidikan Responden

d) Jenis Pekerjaan

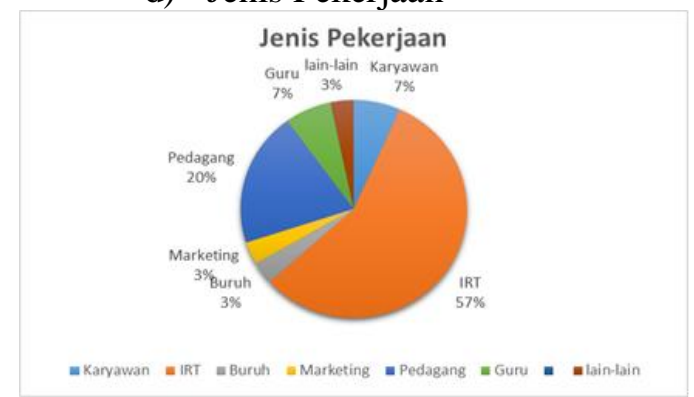

Gambar 4. Diagram Jenis Pekerjaan Responden

2) Profil Pasangan Responden Penelitian

a) Jenis Kelamin

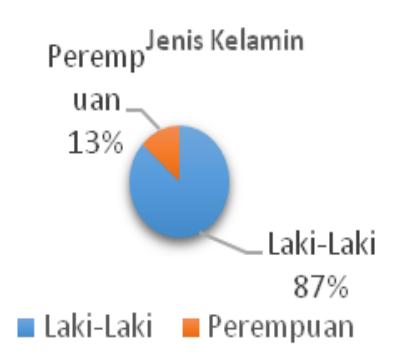

Gambar 5. Diagram Jenis Kelamin Pasangan Responden b) Usia Pasangan Responden

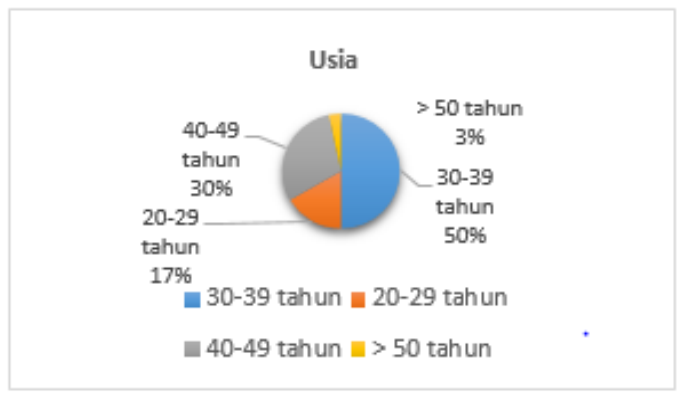

Gambar 6. Diagram Usia Pasangan Responden

c) Pendidikan Pasangan Responden

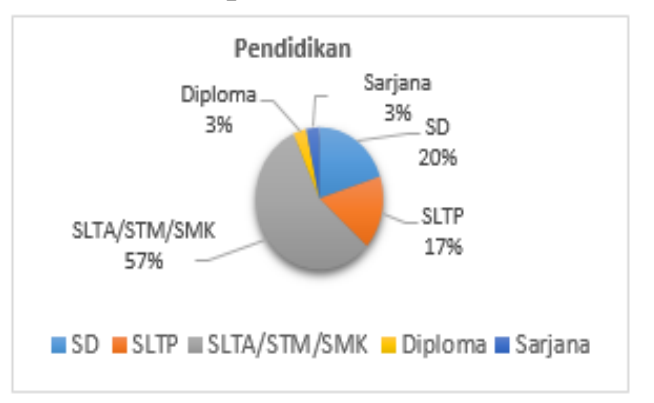

Gambar 7. Diagram Pendidikan Pasangan Responden

d) Jenis Pekerjaan Pasangan Responden

= Karyawan $\square$ IRT

Gambar 8. Diagram Jenis Pekerjaan Pasangan Responden

2. Deskripsi khusus

a. Pengetahuan Parenting

1) Mencari lebar interval untuk mempermudah kategori persentase variabel sangat tinggi, tinggi, cukup rendah, rendah dan sangat rendah. 
Tabel 1. Pengetahuan Parenting

\begin{tabular}{|c|c|c|c|c|c|}
\hline & & Frequency & Percent & Valid Percent & $\begin{array}{l}\text { Cumulative } \\
\text { Percents }\end{array}$ \\
\hline & 70.00 & 1 & 3.3 & 3.3 & 3.3 \\
\hline & 73.00 & 2 & 6.7 & 0.7 & 10.0 \\
\hline & 75.00 & 1 & 3.3 & 3.3. & 13.3 \\
\hline & 70.00 & 1 & 3.3 & 3.3 & 10.7 \\
\hline & 78.00 & 2 & 0.7 & 0.7 & 23.3 \\
\hline & 70.00 & 1 & 3.3 & 3.3 & 20.7 \\
\hline & 82.00 & 1 & 3.3 & 3.3 & 30.0 \\
\hline & 83.00 & 3 & 10.0 & 10.0 & 40.0 \\
\hline & 84.00 & 1 & 3.3 & 3.3 & 43.3 \\
\hline & 85.00 & 2 & 6.7 & 0.7 & 50.0 \\
\hline \multirow[t]{11}{*}{ Valid } & 80.00 & 2 & 0.7 & 0.7 & 50.7 \\
\hline & 87.00 & 1 & 3.3 & 3.3 & $\infty .0$ \\
\hline & 80.00 & 3 & 10.0 & 10.0 & 70.0 \\
\hline & $00 . \infty$ & 1 & 3.3 & 3.3 & 73.3 \\
\hline & 01.00 & 1 & 3.3 & 3.3. & 70.7 \\
\hline & 92.00 & 1 & 3.3 & 3.3 & 50.0 \\
\hline & 93.00 & 1 & 3.3 & 3.3 & 83.3 \\
\hline & 04.00 & 2 & 0.7 & 0.7 & $\infty .0$ \\
\hline & 08.00 & 2 & 0.7 & 0.7 & $\infty 0.7$ \\
\hline & 20.00 & 1 & 3.3 & 3.3 & 100.0 \\
\hline & Total & 30 & 100.0 & 100.0 & \\
\hline
\end{tabular}

Berdasarkan pada tabel 4.2 di atas, variabel pengetahuan parenting skor maksimum adalah sebesar 96,00 dan skor minimum sebesar 70,00. Berdasarkan tabel di atas diperoleh rentang skor sebesar 26. Jika skor pengetahuan parenting disusun kedalam tabel distribusi frekuensi dengan lima katagori, maka setiap kategori rentang interval sebesar5,4di bulatkan menjadi 5 .

2) Menetapkan Klasifikasi Pengetahuan Parenting

Berdasarkan skor maksimal, skor minimum dan lebar interval dapat diklasifikasikan sebagai berikut.

Tabel 2. Distribusi Frekuensi Pengetahuan Parenting

\begin{tabular}{|c|c|c|}
\hline Skor & F & Kategori \\
\hline $96,00-92,00$ & 8 & Sangat tinggi \\
\hline $91,00-87,00$ & 6 & Tinggi \\
\hline $86,00-82,00$ & 10 & Sedang \\
\hline $81,00-77,00$ & 3 & Rendah \\
\hline $76,00-70,00$ & 5 & Sangat rendah \\
\hline
\end{tabular}

b. Keterlibatan Orangtua di Lembaga PAUD

1) Mencari lebar interval untuk mempermudah kategori persentase variabel sangat tinggi, tinggi, cukup rendah, rendah dan sangat rendah.

Tabel 3. Keterlibatan Orangtua

\begin{tabular}{|r|r|r|r|r|}
\hline & Frequency & Peroent & Valid Percent & \multicolumn{1}{|c|}{$\begin{array}{c}\text { Cumulative } \\
\text { Percens }\end{array}$} \\
\hline 33.00 & 2 & 0.7 & 0.7 & 0.7 \\
35.00 & 2 & 0.7 & 0.7 & 13.3 \\
30.00 & 3 & 10.0 & 10.0 & 23.3 \\
37.00 & 1 & 3.3 & 3.3 & 20.7 \\
38.00 & 1 & 3.3 & 3.3 & 30.0 \\
30.00 & 1 & 3.3 & 3.3 & 33.3 \\
40.00 & 2 & 0.7 & 0.7 & 40.0 \\
41.00 & 2 & 0.7 & 0.7 & 40.7 \\
42.00 & 2 & 0.7 & 0.7 & 53.3 \\
43.00 & 2 & 0.7 & 0.7 & 00.0 \\
44.00 & 2 & 0.7 & 0.7 & 00.7 \\
46.00 & 2 & 0.7 & 0.7 & 73.3 \\
47.00 & 1 & 3.3 & 3.3 & 70.7 \\
40.00 & 2 & 0.7 & 0.7 & 33.3 \\
50.00 & 1 & 3.3 & 3.3 & 50.7 \\
52.00 & 1 & 3.3 & 3.3 & 00.0 \\
53.00 & 3 & 10.0 & 10.0 & 100.0 \\
Total & 30 & 100.0 & 100.0 & \\
\hline
\end{tabular}

Berdasarkan pada tabel 4.4 di atas variabel keterlibatan orangtua di lembaga PAUD skor maksimum adalah sebesar 53,00 dan skor minimum sebesar 33,00. Berdasarkan tabel di atas diperoleh rentang skor sebesar 20. Jika skor keterlibatan orangtua disusun kedalam tabel distribusi frekuensi dengan lima katagori, maka setiap kategori rentang interval sebesar4, 2di bulatkan menjadi 4 .

2) Menetapkan Klasifikasi Keterlibatan Orangtua di lembaga PAUD

Berdasarkan skor maksimal, skor minimum dan lebar interval dapat diklasifikasikan sebagai berikut. 
Tabel 4. Distribusi Frekuensi Keterlibatan Orangtua

\begin{tabular}{|c|c|c|}
\hline Skor & F & Kategori \\
\hline $53,00-50,00$ & 5 & Sangat tinggi \\
\hline $49,00-46,00$ & 5 & Tinggi \\
\hline $45,00-42,00$ & 4 & Sedang \\
\hline $41,00-38,00$ & 7 & Rendah \\
\hline $37,00-33,00$ & 9 & Sangat rendah \\
\hline
\end{tabular}

c. Uji Persyaratan Analisis

1) Uji Normalitas

Uji normalitas merupakan salah satu dari bagian uji persyaratan analisa data atau uji asmusi klasik, yang mana memiliki pengertian sebelum melakukan analisa yang sebenernya, data penelitian tersebut harus di uji kenormalan distribusinya. Persyaratan uji normalitas jika nilai signifikasi lebih besar dari 0,05 maka data tersebut dapat dikatakan berdistribusi normal, jika sebaliknya nilai signifikasi lebih kecil dari 0,05 maka data tersebut dinyatakan tidak berdistribusi normal. Berikut adalah tabel hasil perhitungan uji normalitas data :

\section{Tabel 5. Uji Normalitas}

\begin{tabular}{|c|c|c|c|}
\hline \multicolumn{4}{|c|}{ One-Sample Kolmogorov-Smirnov Test } \\
\hline & & Pengetahuan & Keterlibatan \\
\hline $\mathrm{N}$ & & 30 & 30 \\
\hline \multirow[t]{2}{*}{ Normal Parameters ${ }^{\mathrm{a}, \mathrm{b}}$} & Mean & 85.1000 & 42.5333 \\
\hline & Std. Deviation & 7.33602 & 6.19083 \\
\hline \multirow[t]{3}{*}{ Most Extreme Differences } & Absolute & .103 & .088 \\
\hline & Positive & .069 & .088 \\
\hline & Negative & $\cdot 103$ & .085 \\
\hline Kolmogorov-Smimov Z & & 561 & 480 \\
\hline Asymp. Sig. (2-tailed) & & .911 & .975 \\
\hline
\end{tabular}

Berdasarkan hasil uji normalitas pada tabel 4.6 diatas, maka dapat dinyatakan bahwa data pengetahuan parenting orangtua dan keterlibatan orangtua di lembaga PAUD berdistribusi normal, dengan demikian maka dapat digunakan untuk diambil inferensinya.
2) Uji Hipotesis
a) Persamaan Sederhana
Regresi Linear

Tabel 6. Persamaan Regresi

Tabel. 4.7 Persamaan Regresi

Coefficients $^{\mathrm{a}}$

\begin{tabular}{|ll|r|r|r|r|r|}
\hline \multirow{2}{*}{ Model } & & \multicolumn{2}{|c|}{ Unstandardized Coefficients } & $\begin{array}{c}\text { Standardized } \\
\text { Coefficients }\end{array}$ & & \\
\cline { 2 - 5 } & \multicolumn{1}{|c|}{$\mathrm{B}$} & \multicolumn{1}{c|}{ Std. Erroj } & \multicolumn{1}{|c|}{ Beta } & \multicolumn{1}{c|}{ Sig. } \\
\hline 1 & (Constant) & 15.902 & 12.649 & & 1.257 & .219 \\
& Pengetahuan & .313 & .148 & .371 & 2.113 & .044 \\
\hline
\end{tabular}

a. Dependent Variable: Keterlibatan

$$
\hat{Y}=15,902+0,313 \mathrm{X}
$$

Sehingga model persamaan regresinya adalah $\hat{Y}=15,902+$ $0,313 X$. Dari persamaan regresi di atas dapat dibaca "setiap peningkatan 1 skor nilai Pengetahuan Parenting (X) akan meningkatkan Keterlibatan Orangtua sebesar 0,313 pada nilai awal 15,902 ".

b) Uji Signifikasi dan Linearitas Regresi Sederhana

(1) Uji Signifikasi (Uji F)

Tabel 7. Anova Tabel Regresi Sederhana

\section{Tabel 4.8 Anora Tabel Regresi Sederhhana}

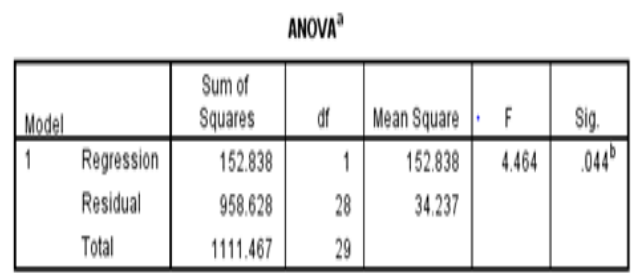

Maka diketahui bahwa nilai F tabel sebesar 4,18. Karena nilai $\mathrm{F}$ hitung 4,464 lebih besar dari nilai $\mathrm{F}$ tabel 4,18 dengan nilai (Sig) sebesar 0,44 maka dapat ditarik kesimpulan bahwa Pengetahuan Parenting (X) berpengaruh signifikan terhadap Keterlibatan Orangtua di lembaga PAUD. 
(2) Uji Linearitas

Tabel 8. Anova Tabel Linear Sederhana

Tabel. 4.9 Anova Table Linear Sederhana

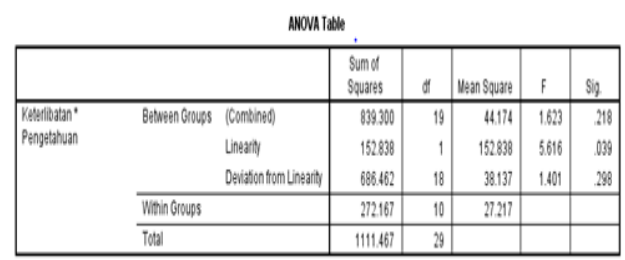

Berdasarkan dari hasil uji linieritas pada output tabel 4.9 "Anova Table" diketahui bahwa nilai signifikasi Devitiation From Linearity sebesar 0,298 karena nilai Sig.0,298 > 0.05 dan nilai F. Devitiation atau F hitung sebesar 1, 401 sedangkan untuk $\mathrm{F}$ tabel sebesar 2,85 (nilai $\mathrm{F}$ tabel dapat dilihat pada lampiran halaman 138). Maka karena $\mathrm{F}$ hitung 1,401 lebih kecil (<) dari F.Tabel 2,85 dapat disimpulkan Ho ditolak Ha diterima, artinya persamaan regresi $\hat{Y}=15,902+0,313 X$ linear.

\section{(3) $\operatorname{Uji} \quad \mathrm{R}^{2} \quad$ (Analisis Determinasi)}

Tabel 9. Model Summary

Tabel.4.10 Model Summary

Model Summary
\begin{tabular}{|l|l|r|r|r|}
\hline Model & $R$ & R Square & $\begin{array}{c}\text { Adjusted R } \\
\text { Square }\end{array}$ & $\begin{array}{c}\text { Std. Error of } \\
\text { the Estimate }\end{array}$ \\
\hline 1 & $.371^{\mathrm{d}}$ & .138 & .107 & 5.85122 \\
\hline
\end{tabular}

Dari hasil output di atas diketahui bahwa nilai $\mathrm{R}$ yang dapat disebut koefisien korelasi antara Pengetahuan Parenting dengan Keterlibatan Orangtua di lembaga PAUD 0,371. Nilai $\mathrm{R}$ square yang dapat disebut koefisien determinasi adalah 0,138 atau $13,8 \%$ artinya besaran pengaruh pengetahuan parenting (X) sebesar 13,8\% sedangkan $86,2 \%$ keterlibatan orangtua di lembaga PAUD (Y) dipengaruhi oleh faktor lainnya yang tidak diteliti dalam penelitian ini.

\section{B. Pembahasan}

Dari 30 responden yang merupakan orangtua yang menyekolahkan anak di PAUD Hubbul Wathon dan PAUD Nusa Indah peneliti mendapatkan data tambahan, yaitu:

1. Orangtua berkomunikasi tentang perkembangan anak pada saat mengantar anak ke sekolah.

2. Orangtua mengkomunikasikan kepada pihak lembaga PAUD berkaitan dengan ketidakhadiran anak didalam kelas dilakukan melalui sms/whatsapp ataupun telfon.

Berdasarkan analisis tingkatan bentuk keterlibatan orangtua data dari hasil perhitungan pada masing-masing bentuk keterlibatan orangtua di lembaga PAUD Hubbul Wathon dan Nusa Indah yang dilakukan oleh orangtua pada kategori sering dan sangat sering hanya berjumlah 3 bentuk keterlibatan orangtua yaitu bentuk keterlibatan penyuluhan orangtua, medampingi anak belajar, dan membantu mengulang kembali materi yang telah diberikan oleh sekolah.

Berdasarkan dari hasil olah data diketahui besarnya pengaruh Pengetahuan Parenting terhadap Keterlibatan Orangtua di lembaga PAUD diperoleh hasil nilai $\mathrm{R}$ square sebesar 0,138 atau $13,8 \%$ dalam artian besaran pengaruh Pengetahuan Parenting (Y) sebesar 13,8\% sedangkan 86,2\% Keterlibatan Orangtua di lembaga PAUD dipengaruhi oleh faktor lainnya dengan model persamaan regresinya adalah $\hat{Y}=15,902+0,313$ X.Dari persamaan regresi di atas dapat dibaca "setiap peningkatan 1 skor nilai Pengetahuan Parenting (X) akan meningkatkan Keterlibatan Orangtua sebesar 0,313 pada nilai awal 15,902 ".

Hasil data deskriptif angket pernyataan yang menunjukkan bahwa Keterlibatan Orangtua di lembaga PAUD masih berada dalam katagori rendah yaitu (1) terlibat dalam penentuan tema pada pelatihan orangtuadan (2) menyalurkan aspirasi pihak sekolah dan orangtua dalam mendukung dan membantu kemajuan pendidikan anak. Sedangkan untuk Pengetahuan Parenting masih berada dalam 
kategori rendah yaitu (1) lingkungan yang menarik.

Hasil dari tabel frekuensi kedua variabel tersebut memiliki jawaban yang menyebar tidak hanya pada 1 katagori saja. Keterlibatan Orangtua di lembaga PAUD berada dalam katagori rendah karena masih kurangnya kerjasama antara pihak lembaga PAUD dengan orangtua sehingga masih perlu ditingkan kembali. Berbeda dengan Pengetahuan Parenting yang sudah dapat dikatakan cukup baik yaitu pada kategori sedang, namun dikarenakan jumlah frekuensi pada katagori tinggi tidak berbeda jauh dengan katagori sedang bahkan sampai dengan yang sangat rendah jadi Pengetahuan Parenting juga tetap perlu ditingkatkan kembali.

Seperti yang dikemukakan Jeynes dalam Amini (2015:9,vol.10) batasan keterlibatan orangtua ialah partisipasi orangtua dalam proses pendidikan dan pengalaman bagi anak mereka, meliputi keterlibatan orangtua berbasis di rumah juga termasuk keterlibatan orangtua di sekolah. Keterlibatan orangtua dapat meliputi: memelihara arah kemajuan anak, sering berkomunikasi dengan guru, memastikan bahwa anak-anak menikmati tantangan, kelas pembelajaran yang baik,serta anak diarahkan untuk memiliki motivasi untuk dapat berprestasi tinggi. Namun dilihat dari hasil analisa penelitian keterlibatan orangtua dalam proses pendidikan dan pengalaman bagi anak masih dikatakan sangat rendah, kesadaran akan pentingnya keterlibatan orangtua masih kurang.

Berkaitan dengan keterlibatan orangtua pengetahuan yang dimiliki oleh orangtua menjadi salah satu faktor yang dapat mempengaruhi keterlibatan orangtua seperti yang dikemukanan oleh Hoover-Demsey dalam Silvia dan Pradana (2015: 15, vol. 4, no. 1) bahwa persepsi orangtua terhadap pengetahuan dan keterampilan yang mereka miliki berkaitan untuk membuat ide-ide bentuk aktivitas keterlibatan juga menjadi faktor pendorong dalam keterlibatan orangtua.

\section{SIMPULAN DAN SARAN}

\section{A. Simpulan}

Hasil analisis data menunjukkan bahwa : "penelitian ini adalah terdapat pengaruh Pengetahuan Parenting terhadap Keterlibatan Orangtua di lembaga PAUD Hubbul Wathon dan PAUD Nusa Indah". Penelitian ini menghasilkan kesimpulan bahwa hipotesis dapat diterima dimana model persamaan regresinya adalah $\hat{Y}=15,902+0,313 X$.

Adapun besaran pengaruh Pengetahuan Parenting terhadap Keterlibatan Orangtua di lembaga PAUD adalah sebesar 13,8\% sedangkan $86,2 \%$ lainnya dipengaruhi oleh faktor lain yang tidak diteliti dalam penelitian ini.

Berkaitan dengan kategori Pengetahuan Parenting dan Keterlibatan Orangtua di lembaga PAUD, dari hasil tabel frekuensi pada variabel Keterlibatan Orangtua di lembaga PAUD, menunjukkan nilai paling dominan adalah 9 pada kolom katagori sangat rendah, yang mana hal ini menunjukan bahwa Keterlibatan Orangtua di lembaga PAUD masih sangat rendah dan masih perlu ditingkatkan kembali. Tabel frekuensi pada Pengetahuan Parenting menunjukkan nilai paling dominan adalah 10 pada kolom katagori sedang. Hal ini menunjukkan bahwa Pengetahuan Parenting yang dimiliki oleh orangtua sedang atau sudah cukup baik, namun dikarenakan jumlah frekuensi dari yang sangat tinggi sampai dengan sangat rendah tidak berbeda jauh, sehingga Pengetahuan Parenting tetap perlu ditingkatkan.

Selanjutnya dari hasil analisa dapat diketahui bahwa bentuk keterlibatan orangtua yang paling tinggi dilakukan oleh orangtua di lembaga PAUD adalah bentuk keterlibatan penyuluhan orangtua, mendampingi anak belajar dan membantu anak mengulang kembali materi yang diberikan oleh orangtua.

\section{B. Saran}

Berdasarkan dari hasil pembahasan penelitian dan kesimpulan yang telah dilakukan oleh peneliti, maka peneliti mengemukakan beberapa saran berkaitan dengan upaya yang dapat meningkatkan Pengetahuan Parenting dan Keterlibatan Orangtua di lembaga PAUD yaitu:

1. Pengetahuan Parenting

Sebaiknya setiap orangtua dapat meningkatkan pengetahuannya mengenai parenting, walaupun dari hasil penelitian menunjukan bahwa pengetahuan parenting yang dimiliki orangtua sedang, namun jumlah orangtua yang memiliki pengetahuan tinggi sampai dengan yang sangat rendah tidak jauh berbeda sehingga perlu ditingkatkan kembali. Hal ini 
bertujuan agar proses interaksi antara orang tua dan anak berkaitan dengan menumbuhkembangkan dan mendidik anak dapat berjalan secara optimal hingga sang anak sudah memenuhi kriteria untuk disebut sebagai pribadi yang dewasa dimana seharusnya orangtua mengetahui dan memahami pengetahuan parenting dengan baik dan benar.

2. Keterlibatan Orangtua

a. Orangtua

Sama halnya dengan pengetahuan parenting sebaiknya orangtua pun dapat meningkatkan keterlibatannyaagar dapat mendukung tumbuh kembang anak secara optimal dimana orangtua menunjukkan suatu derajat dalam hal keterikatan, berpengetahuan dan kesediaan untuk berperan aktif dalam aktivitas anak sehari-hari dalam proses pendidikan dan pengalaman bagi anak mereka, meliputi keterlibatan orangtua berbasis di rumah juga termasuk keterlibatan orangtua di sekolah.

b. Lembaga PAUD

Keterlibatan orangtua akan dapat berjalan dengan baik apabila pihak sekolah atau lembaga PAUD menyediakan atau menyelenggarakan program-program yang dapat mendorong orangtua untuk berpastisipasi aktif di dalamnya, seperti:

1) Untuk meningkatkan komunikasi pihak sekolah sebaiknya menyediakan buku penghubung, agar semua informasi dari pihak sekolah dapat tersampaikan kepada pihak orangtua. Selain itu pihak sekolah juga memastikan bahwa semua orangtua masuk dalam sebuah media komunikasi berupa grup pada telfon celluler. sehingga semua orangtua dapat mengetahui informasi yang akan disampaikan oleh pihak sekolah berkaitan dengan kegiatan yang akan diadakan ataupun informasi lainnya.

2) Untuk meningkatkan pengetahuan orangtua, sebaiknya pihak lembaga PAUD dapat menyediakan pelatihan-pelatihan dan penyuluhan tertentu sehingga dapat meningkatkan pegetahuan orangtua terkait dengan pendidikan dan perkembangan anak.

\section{TINJAUAN PUSTAKA}

Dikbud. (2016). Kemitraan satuan pendidikan anak usia dini (paud) dengan keluarga dan masyarakat. Jakarta: Dikbud.

Hidayati, Z. (2010). Anak Saya tidak nakal kok. Yogyakarta: B First.

Jannah, R. (2012). Pola parenting pada paud tk pelindo dan paud -tk sabilal muthadin kota banjarmasin. Jurnal Ta'alim Muta'allim. Banjarmasin : Vol 4, No7, hal. 22.

Permendikbud No. 146 Tahun 2013 tentang prinsip pendidikan anak usia dini.

Lestari, S. (2012). Psikologi keluarga. Jakarta: Kencana Prenada Media Group.

Retnaningtya, M.S., Paramitha, P.P. (2015). Keterlibatan oarang tua dalam pendidikan anak di tk anak ceria: Jurnal Psikologi Pendidikan dan Perkembangan. Vol 4, No 1, hal. 11-12.

Amini, M. (2015). Profil keterlibatan orang tua dalam pendidikan anak usia TK. Tangerang Selatan. Vol.10 No. 9.

Nurhadi, M. (2012). Pendidikan kedewasaan dalam perspektif islam. Yogyakarta: Deepublish.

Diandha, R. (2015). Keterlibatan orang tua dalam pendidikan anak usia dini di taman kanak kanak. Riau: Jurnal Ilmu Pendidikan dan Pengajaran, Vol 2, No 1 hal. 6

Zaenab, S., Syahbudin. (2012). Profesionalisme guru paud menuju NTB bersaing. Yogyakarta: Deepublish. 